\title{
A general approach to optimize disassembly sequence planning based on disassembly network: A case study from automotive industry
}

\author{
Yu, B. ${ }^{a}$, Wu, E. ${ }^{a}$, Chen, C. ${ }^{b}$, Yang, Y. ${ }^{c}$, Yao, B.Z. ${ }^{b,}{ }^{,}$, Lin, Q. $^{\mathrm{a},{ }^{*}}$ \\ ${ }^{a}$ School of Transportation Science and Engineering, Beihang University, Beijing, P.R. China \\ ${ }^{b}$ Automotive Engineering College, Dalian University of Technology, Dalian, P.R. China \\ ${ }^{c}$ Transportation Management College, Dalian Maritime University, Dalian, P.R. China
}

\begin{abstract}
A B S T R A C T
Disassembly sequences is a key element of products recycling or remanufacturing, and related with the recycling quality or maintenance cost. In order to improve the performance of the disassembly operation, this paper analyzes the disassembly information on automobile parts and draws the disassembly network graph by using evolution rules of the AND/OR graph. Then a disassembly model of automobile parts is established. Considering the mapping between the Floyd-Warshall algorithm and the automobile disassembly mode, we obtain the optimal disassembly sequence by solving the weighted disassembly model. Finally, a case study on automotive silicone oil fan clutch is given to illustrate the procedure. This approach could be used to obtain optimum disassembly routes of products containing complex AND/OR hierarchical relationships.
\end{abstract}

(C) 2017 PEI, University of Maribor. All rights reserved.

\begin{tabular}{l} 
A R T I C L E I N F O \\
\hline Keywords: \\
Automotive industry \\
Automotive parts \\
Disassembly sequence \\
Disassembly model \\
Disassembly network \\
Floyd-Warshall algorithm \\
*Corresponding author: \\
linqf@buaa.edu.cn \\
(Lin, Q.) \\
yaobaozhen@dlut.edu.cn \\
(Yao, B.Z.) \\
Article history: \\
Received 17 January 2017 \\
Revised 21 July 2017 \\
Accepted 19 September 2017
\end{tabular}

\section{References}

[1] Yang, J., Sun, J. (2015). Vehicle path reconstruction using automatic vehicle identification data: An integrated particle filter and path flow estimator, Transportation Research Part C: Emerging Technologies, Vol. 58, 107-126, doi: 10.1016/j.trc.2015.07.003.

[2] Behdad, S., Thurston, D. (2012). Disassembly and reassembly sequence planning tradeoffs under uncertainty for product maintenance, Journal of Mechanical Design, Vol. 134, No. 4, 169-184, doi: 10.1115/1.4006262.

[3] Gerner, S., Kobeissi, A., David, B., Binder, Z., Descotes-Genon, B. (2005). Integrated approach for disassembly processes generation and recycling evaluation of an end-of-life product, International Journal of Production Research, Vol. 43, No. 1, 195-222, doi: 10.1080/00207540412331270414.

[4] Lambert, A.J.D. (2003). Disassembly sequencing: A survey, International Journal of Production Research, Vol. 41, No. 16, 3721-3759, doi: 10.1080/0020754031000120078.

[5] Li, J.R., Khoo, L.P., Tor, S.B. (2005). An object-oriented intelligent disassembly sequence planner for maintenance, Computers in Industry, Vol. 56, No. 7, 699-718, doi: 10.1016/j.compind.2005.03.005.

[6] Lambert, A.J.D. (1999). Linear programming in disassembly/clustering sequence generation, Computers \& Industrial Engineering, Vol. 36, No. 4, 723-738, doi: 10.1016/S0360-8352(99)00162-X.

[7] Moore, K.E., Güngör, A., Gupta, S.M. (2001). Petri net approach to disassembly process planning for products with complex AND/OR precedence relationships, European Journal of Operational Research, Vol. 135, No. 2, 428449, doi: 10.1016/S0377-2217(00)00321-0. 
[8] Li, D.Q., Fu, B.W., Wang, Y.P., Lu, G.Q., Berezin, Y., Stanley, H.E., Havlin, S. (2015). Percolation transition in dynamical traffic network with evolving critical bottlenecks, In: Proceedings of the National Academy of Sciences, Vol. 112, No. 3, 669-672, doi: 10.1073/pnas.1419185112.

[9] Zhang, H.C., Kuo, T.C. (1996). A graph-based approach to disassembly model for end-of-life product recycling, In: Proceedings of the Nineteenth IEEE/CPMT International Electronics Manufacturing Technology Symposium, Austin, USA, 247-254, doi: 10.1109/IEMT.1996.559739.

[10] Zhang, H.C., Kuo, T.C., Lu, H., Huang, S.H. (1997). Environmentally conscious design and manufacturing: A stateof-the-art survey, Journal of Manufacturing Systems, Vol. 16, No. 5, 352-371, doi: 10.1016/S0278-6125(97) 88465-8.

[11] Tiwari, M.K., Sinha, N., Kumar, S., Rai, R., Mukhopadhyay, S.K. (2002). A petri net based approach to determine the disassembly strategy of a product, International Journal of Production Research, Vol. 40, No. 5, 1113-1129, doi: $10.1080 / 00207540110097176$.

[12] Zussman, E., Zhou, M.C. (2000). Design and implementation of an adaptive process planner for disassembly processes, IEEE Transactions on Robotics Automation, Vol. 16, No. 2, 171-179, doi: 10.1109/70.843173.

[13] Tang, Y., Zhou, M., Gao, M. (2006). Fuzzy-petri-net-based disassembly planning considering human factors, IEEE Transactions on Systems, Man, and Cybernetics - Part A: Systems and Humans, Vol. 36, No. 4, 718-726, doi: 10.1109/TSMCA.2005.853508.

[14] Gao, J., Dong, X., Chen, H., Duan, G., Wang, J. (2003). Disassembly AND/OR graph model for "disassembly for recycling", In: Proceedings of the IEEE International Symposium on Electronics and the Environment, 2003, Boston, USA, 54-59, doi: 10.1109/ISEE.2003.1208047.

[15] Kongar, E., Gupta, S.M. (2006). Disassembly sequencing using genetic algorithm, The International Journal of Advanced Manufacturing Technology, Vol. 30, No. 5-6, 497-506, doi: 10.1007/s00170-005-0041-x.

[16] Adenso-Díaz, B., García-Carbajal, S., Lozano, S. (2007). An efficient grasp algorithm for disassembly sequence planning, OR Spectrum, Vol. 29, No. 3, 535-549, doi: 10.1007/s00291-005-0028-x.

[17] Failli, F., Dini, G. (2001). Optimization of disassembly sequences for recycling of end-of-life products by using a colony of ant-like agents, In: Proceedings of the 14th International Conference on Industrial and Engineering Applications of Artificial Intelligence and Expert Systems, IEA/AIE 2001, Budapest, Hungary, 632-639, doi: 10.1007/ 3-540-45517-5 70.

[18] McGovern, S.M., Gupta, S.M. (2006). Ant colony optimization for disassembly sequencing with multiple objectives, The International Journal of Advanced Manufacturing Technology, Vol. 30, No. 5-6, 481-496, doi: 10.1007 Ls00170-005-0037-6.

[19] Lye, S.W., Lee, S.G., Khoo, M.K. (2000). An algorithm for optimizing the servicing of products with constrained, multiple defects, International Journal of Production Research, Vol. 38, No. 10, 2185-2200, doi: 10.1080/002075 40050028043.

[20] González, B., Adenso-Díaz, B. (2006). A scatter search approach to the optimum disassembly sequence problem, Computers Operations Research, Vol. 33, No. 6, 1776-1793, doi: 10.1016/j.cor.2004.11.018.

[21] Kang, J.-G., Xirouchakis, P. (2006). Disassembly sequencing for maintenance: A survey, Proceedings of the Institution of Mechanical Engineers Part B Journal of Engineering Manufacture, Vol. 220, No. 10, 1697-1716, doi: 10.1243/09544054JEM596.

[22] Behdad, S., Kwak, M., Kim, H., Thurston, D. (2010). Simultaneous selective disassembly and end-of-life decision making for multiple products that share disassembly operations, Journal of Mechanical Design, Vol. 132, No. 4, doi: $10.1115 / 1.4001207$.

[23] Srinivasan, H., Gadh, R. (1998). A geometric algorithm for single selective disassembly using the wave propagation abstraction, Computer-Aided Design, Vol. 30, No. 8, 603-613, doi: 10.1016/s0010-4485(98)00009-8.

[24] Srinivasan, H., Figueroa, R., Gadh, R. (1999). Selective disassembly for virtual prototyping as applied to demanufacturing, Robotics and Computer-Integrated Manufacturing, Vol. 15, No. 3, 231-245, doi: 10.1016/S07365845(99) 00023-X.

[25] Kara, S., Pornprasitpol, P., Kaebernick, H. (2005). A selective disassembly methodology for end-of-life products, Assembly Automation, Vol. 25, No. 2, 124-134, doi: 10.1108/01445150510590488.

[26] Chung, C., Peng, Q. (2005). An integrated approach to selective-disassembly sequence planning, Robotics and Computer-Integrated Manufacturing, Vol. 21, No. 4-5, 475-485, doi: 10.1016/j.rcim.2004.11.008.

[27] Peng, Z., Shan, W., Guan, F., Yu, B. (2016). Stable vessel-cargo matching in dry bulk shipping market with price game mechanism, Transportation Research Part E Logistics Transportation Review, Vol. 95, 76-94, doi: 10.1016 Li.tre.2016.08.007.

[28] Yao, B., Chen, C., Cao, Q., Jin, L., Zhang, M., Zhu, H., Yu, B. (2016). Short-term traffic speed prediction for an urban corridor, Computer-Aided Civil and Infrastructure Engineering, Vol. 32, No. 2, 154-169, doi: 10.1111/mice.12221.

[29] Yao, B., Hu, P., Lu, X., Gao, J., Zhang, M. (2014). Transit network design based on travel time reliability, Transportation Research Part C Emerging Technologies, Vol. 43, 233-248, doi: 10.1016/j.trc.2013.12.005.

[30] Yu, B., Kong, L., Sun, Y., Yao, B., Gao, Z. (2015). A bi-level programming for bus lane network design, Transportation Research Part C Emerging Technologies, Vol. 55, 310-327, doi: 10.1016/i.trc.2015.02.014.

[31] Tang, Y., Zhou, M., Zussman, E., Caudill, R. (2002). Disassembly modeling, planning and application, Journal of Manufacturing Systems, Vol. 21, No. 3, 200-217, doi: 10.1016/S0278-6125(02)80162-5.

[32] Yao, B., Yu, B., Hu, P., Gao, J., Zhang, M. (2016). An improved particle swarm optimization for carton heterogeneous vehicle routing problem with a collection depot, Annals of Operations Research, Vol. 242, No. 2, 303-320, doi: $10.1007 / \mathrm{s} 10479-015-1792-\mathrm{x}$.

[33] Yu, B., Wang, Y.T., Yao, J.B., Wang, J.Y. (2016). A comparison of the performance of ANN and SVM for the prediction of traffic accident duration, Neural Network World, Vol. 26, No. 3, 271-287, doi: 10.14311/NNW.2016. $\underline{26.015}$. 


\title{
Splošni pristop za optimizacijo zaporedja demontaže na podlagi demontažne mreže: študija primera iz avtomobilske industrije
}

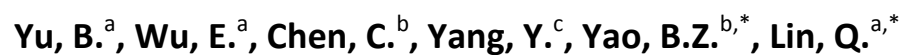 \\ ${ }^{a}$ School of Transportation Science and Engineering, Beihang University, Beijing, P.R. China \\ ${ }^{b}$ Automotive Engineering College, Dalian University of Technology, Dalian, P.R. China \\ 'Transportation Management College, Dalian Maritime University, Dalian, P.R. China
}

\section{POVZETEK}

Zaporedje demontaže izdelka je ključnega pomena pri recikliranju ali predelavi izdelkov in je povezano s kakovostjo recikliranja oz. stroški vzdrževanja. Da bi izboljšali učinkovitost operacij demontaže, prispevek analizira podatke o razstavljanju avtomobilskih delov in izdela mrežni diagram demontaže z uporabo evolucijskih pravil IN/ALI. Nato se vzpostavi model demontaže avtomobilskih delov. Upoštevajoč mapiranje med algoritmom Floyd-Warshall in načinom razstavljanja avtomobila dobimo optimalno zaporedje razstavljanja z reševanjem obteženega modela demontaže. Za ilustracijo predlagane metode je na koncu prispevka prikazana še študija primera za primer demontaže avtomobilske sklopke ventilatorja. Predstavljen pristop se lahko uporabi za pridobitev optimalnih poti demontaže izdelkov s kompleksnimi IN/ALI hierarhičnimi odnosi.

(C) 2017 PEI, University of Maribor. All rights reserved.

\section{PODATKI O ČLANKU}

Ključne besede:

Avtomobilska industrija

Avtomobilski deli

Zaporedje demontaže

Model demontaže

Demontažna mreža

Floyd-Warshall algoritem

*Kontaktna oseba:

linqf@buaa.edu.cn

(Lin, Q.)

yaobaozhen@dlut.edu.cn

(Yao, B.Z.)

Zgodovina članka:

Prejet 17. januarja 2017

Popravljen 21. julija 2017

Sprejet 19. septembra 2017 